\title{
Hume, Newton and Malebranche on Causation
}

\author{
John H. Dreher \\ University of Southern California, Los Angeles, CA, USA \\ Email: dreher@usc.edu
}

How to cite this paper: Dreher, J. H. (2017). Hume, Newton and Malebranche on Causation. Open Journal of Philosophy, 7, 329-352.

https://doi.org/10.4236/ojpp.2017.73018

Received: May 29, 2017

Accepted: July 24, 2017

Published: July 27, 2017

Copyright (c) 2017 by author and Scientific Research Publishing Inc. This work is licensed under the Creative Commons Attribution International License (CC BY 4.0).

http://creativecommons.org/licenses/by/4.0/ (c) (i) Open Access

\begin{abstract}
Hume, Newton and Malebranche have been made out to be an odd couple, united in the belief that prior Aristotelian and Cartesian analyses of causation are inadequate; yet differing in the correctives they offer to relieve those earlier misconceptions. Malebranche famously appeals to God to validate his occasionalist account of causation. Newton appeals to God to explain forces like gravity which is revealed by necessary laws like the Law of Universal Gravitation. Hume, on the other hand, seeks to explain causation as a natural phenomenon that can be explained by his theory of belief formation. This paper argues that the difference between Malebranche and Hume runs much deeper than their substantive analyses of causation; they also differ about experimental reasoning and natural philosophy in which Newton makes room for God as an integral part of natural philosophy but not experimental science whereas Malebranche thinks of God as an essential part of experimental science. More specifically, this paper hopes to make original contributions by arguing 1) that although Hume does not think of the grand laws of nature (from Galileo and Newton) as necessities but rather as mere universal regularities, like "the sun will rise tomorrow" and "all men must dye", he carefully makes room for a unique place for the grand laws of physics by distinguishing quotidian regularities from those grand laws by virtue of their specificity and comprehensiveness. This paper also argues 2) that Hume conceived of the grand laws of nature as operating in ideal circumstances, which explains why it is that apparent exceptions to those laws do not undermine them. The paper argues in conclusion that 3) Hume is not "Malebranche minus God", that 4) Newton is not in a better position than Hume to contemplate nature's twists and turns and finally that 5) to imagine a time at which the sun does not rise or a man who simply does not ever die is not to imagine a weird and inexplicable anomaly but rather to imagine that the entire course of nature has changed.
\end{abstract}

\section{Keywords}

Hume, Malebranche, Newton, Experimental Reasoning, God, Occasionalism 


\section{Introduction}

David Hume (1710-11) was an empiricist who holds that no ideas are innate, which is to say that they all come from experiences. Obviously this led Hume to the conclusion that our idea of causal powers must somehow originate in experience, even though he also believed that no cause could necessitate its effect if only because every cause can be conceived to occur without its effect. Nicolas Malebranche (1638-1715) was a Cartesian, meaning among other things that Malebranche accepted the notion that some ideas are innate, principally the idea of God. Malebranche believed that only God is a true causal agent because it is always possible to think of a cause without its effect without contradiction, except in the case of causation by God. Finally, Newton (1642-1727) distinguished carefully between experimental reasoning and natural philosophy. Newton asserted that there are universal regularities in nature that are described by his famous laws of motion, but Newton did not attribute those regularities to any ultimate sources from the standpoint of empirical science. However, Newton did believe that the laws of motion are expressions of natural forces, like gravity, which, as a matter of natural philosophy, could be attributed to God. ${ }^{1}$ According to Newton, experimental (or empirical) science deals only with theories that can be tested by observation and experiment; natural philosophy includes experimental science but also countenances hypotheses that cannot be tested, principally hypotheses about God (Newton, 1718, Clark Trans., 1718; Ariew \& Watkins, 2009: p. 293); also (Newton, 1713, Motte Trans., 1729; Ariew \& Watkins, 2009: p. 290). Both Malebranche and Newton deeply influenced Hume. Hume certainly accepted Newton's laws of motion as a consequence of experimental reasoning, but unlike Newton, Hume did not think that there are necessities in nature. This raises the problem about the relation of Hume to Newton and to Malebranche. Hume, it appears, agrees with Malebranche that without God there cannot be causal powers; yet he agrees that Newton's laws are indeed true but denies their apparent necessity.

This paper argues that Hume thinks of Newton's laws, and all the laws of empirical science, as universal regularities (extending indefinitely to the future as the past); but this seems to imply that he should also think that there are necessities in nature. However, Hume believes that even if it turns out that there is no time (past, present or future) at which a true law of experimental science fails, each true law remains merely contingent because it is always possible to conceive (think without contradiction) that the law fails. In fact, Hume argues that events are not connected, but merely "loosely associated". Even so, apparent exceptions to the laws do not undermine them, because the laws describe phenomena in ideal circumstances, in which a variety of forces may affect the outcome of events. For examples, in the case of falling objects, the lift of the wind can conflict with the force of gravity, and magnetic attraction can conflict with the im-

\footnotetext{
${ }^{1}$ For an introductory and sophisticated discussion of the philosophies of Hume, Newton and Malebranche, see the pertinent entries in Zalta, E. (Ed.) Stanford Encyclopedia of Philosophy. Metaphysics Research Lab: Center for the Study of Language and Information. http://stanford.plato.edu/ Those entries include: Janiak, A. (2014b). “Newton’s Philosophy” (\$1, 2, 4); Schmaltz, T. (2013). "Nicolas Malebranche" (\$1, 2, 4); Morris \& Brown (2014). "Hume" $(\$ 3,5)$.
} 
pact of colliding objects (Hume, 1739b: SBN, p. 76; Hume, 1739a: N \& N, p. 54).

Walter J. Ott is among the most distinguished commentators on theories of causation of the late $17^{\text {th }}$ and early $18^{\text {th }}$ centuries. In his book, Causation \& Laws of Nature in Early Modern Philosophy, Ott writes: "The old saw that Hume is occasionalism minus God is not too far off the mark" (Ott, 2009a: p. 195), which raises the obvious question: Just how far off the mark is the old saw? This paper argues that it is very far off the mark. Hume sees events "loosely" associated with each other (albeit in regular patterns), in part because events do not occur in ideal circumstances. Some of those regular patterns are causal; ${ }^{2}$ yet, even they are not necessary, despite the facts that they are supported by universal scientific laws, and are necessary to credible explanation (Hume, 1739b: SBN, pp. 7882; Hume, 1739a: N \& N, pp. 56-58). As suggested above, Malebranche acknowledges that events occur in patterns, but it is a mistake to think that those patterns are necessary in themselves. Without reference to the will of God, there isn't any way at all to explain the existence of regularities that are typically attributed to causal powers (Malebranche, 1674-5, Lennon \& Obecalp Trans.; In Nadler, 1992: p. 94f). ${ }^{3}$

Hume too thinks that there are causal patterns, but he thinks that he has made an important discovery, which is that there aren't necessities in nature and therefore there aren't any causal necessities for philosophy to explain. If that is correct, it is obvious just how "the old saw" got ripping: Take away God, and you take away the necessity of causation; and take away the necessity of causation; and viola: you have Hume. In other words, Malebranche thinks that there are causal necessities in nature and that it is the business of philosophy to explain how they are possible, but Hume does not believe that there are causal necessities in nature. Malebranche relies upon God to explain necessity, which appears to be an act of desperation. Hume, on the other hand, thinks that there are only contingent regularities in nature, which hardly comports comfortably with the grand laws of physics. Shall we say, for example, that Newton's Law of UniversL Gravitation just happens to be a regularity of nature; that it just happens that all masses in the universe attract each other in proportion to the product of their masses and inversely to the square of the distances separating them? Does it just happen that water freezes at sea level on Earth at $0^{\circ} \mathrm{C}$ ? It has been suggested that Hume might have regarded the laws as relations of ideas, which mimic mathematical theorems, but this suggestion appears to be ill-advised if only because Hume thinks that the laws of nature can be conceived to be false. ${ }^{4}$ It does not just happen that the gravitational attraction of two masses is inversely proportional to the square of the distance separating them, but neither is it inconceivable that it should be otherwise. I believe that Hume's view is that the laws of nature should be viewed as propositions like "the sun will rise tomorrow" or that,

\footnotetext{
${ }^{2}$ Regular patterns that are not causal include resemblances and even those that are merely sequential or contiguous.

${ }^{3}$ For a more thorough discussion of this point, see: Bell, M. (1997). "Hume and Causal Power: The Influences of Malebranche and Newton" (p. 71f).

${ }^{4}$ This point is widely acknowledged and discussed, for example, by Bell, Ibid. p. 80 .
} 
among the saddest of facts, "all men must dye", "Proofs" of those propositions arise from "arguments which originate in cause and effect, and which are nonetheless entirely free from doubt and uncertainty" (Hume, 1739b: SBN, p. 125; Hume, 1739a: N \& N, p. 86). Indeed comparing the grand laws of physics to truisms like "the sun will rise tomorrow" or "all men must dye" is surprising, but that nevertheless is what Hume does. Even so, there must be a significant difference between those everyday truths and the grand laws of physics. The answer lies in the specificity and comprehensiveness of the laws of physics. So, the deeper difference between Malebranche and Hume (deeper than their difference about God's role in causation) is that for Malebranche causal connections are necessary, and for Hume they are contingent; but as we shall see, that difference does not derive from a difference of opinion about God (though they surely do disagree about God), but rather from a disagreement about scientific explanation. Moreover, their difference about specificity and comprehensiveness facilitate the distinction between the quotidian regularities and grand laws from each other and thereby differentiates experimental science from commonplace wisdom.

\section{The Imprint Theory of Causation and the Problem of Specificity}

In Meditations on First Philosophy Descartes commits himself to the Imprint Theory of Causation (ITC) (Descartes, 1641, Cottingham et al. Trans.: p. 28f). (ITC) essentially claims that a causal explication identifies a sufficient condition for both the existence and the identity of its effect. So, a fire is the cause of a hot frying pan because it explains both the fact that the frying pain underwent a change and it explains the identity of that change. More concisely, the hot fire heated the frying pan. This theory, which prevailed at the time, was not universally endorsed. For example, Gassendi complained that (ITC) should be taken to refer to material and not efficient causes. Moreover, Gassendi claims, even in rare cases, like the relation of parent to child, where some material is certainly passed from parent to child, what is passed is not the essence of the parent. Clearly, the union of the genetic material of mother and father are connected materially to the child, but events are not always (or even usually) connected in that way, and besides even if they were, the connection would not be essential; that is, would not pertain to the essence or identity of the effect (Gassendi, 1621; Cottingham et al., 1984: p. 201).

I shall call the main problem with (ITC) the problem of specificity. The early $17^{\text {th }}$ century marked the beginning of modern mathematical physics. It is not enough to explain why it is that a cannonball falls to the ground. What is also required is an explanation (and prediction) of the time that it will take to fall to the ground, and its velocity when it reaches the ground. In this way, the standard of adequacy for causal explanations was significantly raised during the early modern period by Galileo in Two New Sciences ${ }^{5}$ where Galileo refutes Aristotle's

${ }^{5}$ Galileo, Two New Sciences (1638).pp. 300-367 in Finocchiaro (Trans. and Ed.) (2008). The Essential Galileo. Indianapolis/Cambridge: Hackett Publishing Company. 
account of falling bodies, describes the behavior of the pendulum, analyzes the velocity and uniform acceleration finally establishes the laws of falling bodies and analyzes the parabolic path of projectiles. Incidentally, as I shall later stress, Galileo also recognizes the importance of identifying the circumstances in which phenomena occur. For example analysis of the motion of a ball on an inclined plane presupposes that the plane is perfectly smooth, which is to say frictionless. ${ }^{6}$

To take another example, which is from Hume: it is not enough to explain why it is that food (e.g. bread) nourishes. What is required is an account of precisely what it is in the bread that nourishes just how the process works; ${ }^{7}$ for example, by explaining how the proteins in the bread are hydrolyzed to amino acids. This provides a particularly good example of specificity and the role that it plays in scientific explanation at the micro level, and it is evidence that Hume's intuitions about how natural science advances were on the mark. The process of the hydrolysis of proteins into digestible amino acids involves complicated chemical reactions. Although much early progress was made at the beginning of the $20^{\text {th }}$ century, a major advance in analyzing the complete hydrolysis of peptide bonds was made in 1962, where in their seminal paper, "The Complete EnzymicHydroloysis of Proteins", Hill and Schmidt demonstrated methods that:

"employproteolytic enzymes for hydrolysis of proteins. Our studies demonstrate that digestion of a protein by papain (12), followed by treatment with the purified kidney peptidases, leucineaminopeptidase (13), and prolinase

(14) results in essentially complete hydrolysis of all peptide bonds and gives high yields of tryptophan, glutamine and asparagine" (Hill \& Schmidt, 1962). “The Complete EnzymicHydroloysis of Proteins” (p. 389).

Hydrolysis of proteins into digestible amino acids is an excellent example of what I mean by specificity in scientific explanation. Specificity, I shall argue, is what distinguishes occasionalist (Malebranchian) explanations (God wills whatever occurs) from genuine scientific explanation. We cannot achieve specificity by simply assembling a description of all events and claiming that God wills them one by one. That is because it is the specificity of natural science that integrates all the events into a unified whole that explains more general phenomena (for example, the foregoing account of the hydrolysis of proteins into amino acids that results in the digestion of digestion of bread). Hume agrees with Galileo (and of course with Newton) that without the systematic integration of all pertinent phenomena, there really isn't a scientific explanation at all.

To recur to Descartes, it is not enough to explain the fact that the frying pan became hot; it is necessary to predict just how hot it will get and to explain why it became as hot as it did; in other words, just how the kinetic energy of the fire is "transferred" to the frying pan. I believe that the reason that (ITC) itself fell out of favor because it could not deal with the problem of specificity. In fact, the more complex the mathematics becomes, the less plausible it is to think that a qualitative description of the "identity" of the cause will be sufficient to explain

${ }^{7}$ Hume, D. (1776), Beauchamp, Ed., (2000). pp. 53-57, especially p. 55. 
the particulars of its effect; which raises the inevitable question: How does theory explain the particulars of an effect?

The answer lies in the functional relations that hold among the quantities that are to be predicted and explained. In the case of the early $17^{\text {th }}$ century, the pertinent quantities deal with terrestrial and celestial motion. Galileo's law of freely falling objects is a good and an easy example. The time ( $t$ ) it takes an object to fall to the ground (on Earth) is a function of the distance (d) that it falls and the acceleration of gravity at the surface of the earth (a): $d=1 / 2 \mathrm{at}^{2}$, where a, the acceleration of gravity, is approximately $32 \mathrm{ft} / \mathrm{sec}^{2}$. It follows that if an object is released from 64 feet, it will fall to the ground in 2 seconds, ignoring possible air resistance, among other forces, and rounding the acceleration of gravity down slightly to $32 \mathrm{ft} / \mathrm{sec}^{2}$. So, an analysis of the behavior of freely falling objects does not involve identifying a "quality" and then projecting that quality onto its "effect" in order to explain its "identity".

All this may now be obvious, but Descartes himself acknowledged that he once had attributed the tendency of bodies to fall to their "heaviness", ignoring the fundamental principle of the mechanism that he had already endorsed. Indeed, the "establishment theory" during the early $17^{\text {th }}$ century was still the idea that the motions of bodies depend upon their qualities, which is the defining mark of Aristotle's theory of motion. Aristotle thought of gravity as the quality that explains the tendency of bodies to fall, and of levity as the quality by virtue of which bodies tend to rise. Indeed, this idea is hardlyunintuitive (Aristotle, 335 BCE, Hardie \& Gaye, Trans.: p. 285). In Galileo's law of freely falling bodies we find a key reference to the acceleration of gravity; Newton also attributed the acceleration of falling objects to gravity, although he did not think of gravity as an intrinsic property of objects. Rather, Newton attributed the weight (formerly the heaviness as opposed to the levity) of an object to the gravitational attraction between the object and the point mass of the massive object to which is tends to fall, for example the earth. The gravitational attraction depends in its turn upon the product of the mass of the falling object and the point mass of the earth. Thus mass or bulk enters into the story, although explicit reference to it "drops out" of the law of freely falling bodies; even so, it is implicitly included by reference to the acceleration of gravity at the surface of Earth. The tendency of the body to fall is due to the attraction between its mass and the mass to which it falls, and the measure of that attraction is the weight of the object. That tenden$c y$, the gravitational force, is directly proportional to the mass of the object that is falling. Aristotle (and at one point Descartes) were certainly wrong about the explanation of freely falling objects, but their mistake was neither obvious nor foolish (Feynman, 1965: p. 29).

\subsection{Newton on Gravitational Force and the Communication of Motion}

Malebranche, Hume, and even Newton drew much of their inspiration about motion from examples concerning the direct communication of motion rather 
than from "action at a distance". Indeed, Newton himself thought that action at a distance doesn't make much sense unless acting according to a law of nature also makes sense. For example, with respect to Vis inertia (more or less his own First Law of Motion), Newton writes:

The visinertiae is a passive principle by which bodies persist in their motion or rest, receive motion in proportion to the force impressing it, and resist as much as they are resisted. By this principle alone there could never have been any action in the world. Some other principle was necessary for putting bodies in motion (Newton, 1718, Clark Trans., 1718; Ariew \& Watkins, 2009: p. 291).

I think that it is fair to say that Newton believes that the laws of nature describe nature but that they do not fully explain nature. The issue is not only how nature behaves but also why it behaves as it does rather than in some other way. Newton's answer is that it is ultimately the will of God that answers the "Why?" and the laws of physics that describe the "How?" Newton famously writes in his third letter to Bentley: "Gravity must be caused by an agent acting constantly according to certain laws" (Newton, 1692-93; Thayer, 1953: p. 54); and makes similar claims in his first letter to Bentley (see Guth, 2007: p. 1). But Newton does not speculate on the nature of that agent. ${ }^{8}$ Quite the contrary! Indeed, following the quotation above Newton writes: "but whether this agent be material or immaterial, I have left to the consideration of your readers". In the Scholium to the second edition (1713) of the Mathematical Principles of Natural Philosophy Newton cautions:

Up to now I have not been able to deduce the reason for these properties of gravity from phenomena, and I frame no hypotheses. For whatever is not deduced from the phenomena ought to be called a hypothesis, and whether metaphysical or mechanical have no place in experimental philosophy

(Newton, 1713, Motte Trans., 1729; Ariew \& Watkins, 2009: p. 291).

Experimental reasoning in science and philosophy does not postulate "hypotheses" about the origin of "forces" like gravity because hypotheses that are not validated by "phenomena" do not have a place in experimental science. What we know about gravity is "deduced" from phenomena. Elsewhere, in Optics Query 31, for example, Newton distinguishes experimental reasoning from natural philosophy. God certainly may play an important role in our understanding of the origin and structure of nature (that is, natural philosophy), but that role is not a part of experimental philosophy or as, we would say, physical science (Newton, 1718, Clark Trans., 1718; Ariew \& Watkins, 2009: p. 292f).

\subsection{Malebranche on Motion}

If Newton is at a loss to explain the ultimate origin of communication of motion and motion at a distance, Malebranche is unreceptive to the idea that any mortal could possibly have anything of value to offer on the subject. In the background,

${ }^{8}$ For further discussion see: (Janiak, 2014a: p. 103ff). 
hearkening back to Aquinas, is the idea that causes are endowed with powers, and hence causes are empowered to produce particular effects; however, there were religious reasons for rejecting this account of causation. If ordinary objects or events were endowed with powers that brought about specific effects, would they not be like little gods? Aquinas and others took the position that the powers of ordinary objects or events must be secondary, causes that are dependent only upon the concurrence of the divine (see Ott, 2009a: pp. 106-109).

It seems to me, and many others including Ott, that the ultimate difficulty with the doctrines of secondary causation and concurrence is that they are otiose. If secondary causes are the means by which God brings about change in position, why doesn't God just cause the change directly? If the so-called secondary causes cannot explain effects on their own, then how are we better off with them and God than we are with God alone? Malebranche addresses this line of thought as follows:

Can this body move itself?...suppose this body truly has the power to move itself; in which direction will it go? At what speed...Supposing that this body were surrounded by an infinity of others, what must it do when it encounters a body whose speed and bulk are unknown to it? It will give to it...a portion of its moving force? But what part? How will it communicate this part or propagate its motion?' (Malebranche, 1674: p. 91).

Malebranche despairs of a physics that addresses the specificity of nature. The way in which he deals with specificity is a defining part of his occasionalism. According to Malebranche, God intervenes on the occasion of every event to create its effect. So, to recur to the example from Hume, suppose that someone ingests fresh bread, and that the bread is found to nourish. The occasionalist understanding of this event is that God creates nourishment upon the ingestion of the bread, an account that raises two issues. First, just what causes the eating? Suppose that its cause is an act of free will; but, just how are we to account for the relation of the act of the will and the eating of the bread? Surely a "mental event" will not be a more plausible cause than a physical event in explaining a physical event. It is God to the rescue: The mental event that precedes the physical event occurs along with God's willing it (never mind that the responsibility for the free act remains with the agent)! Secondly, what shall we say about how the bread nourishes? In what does nourishment consists, and of what use is it? Surely its use is providing energy, strength to muscles, and mental acuity; but in what quantities and by what measures? Again, it is God to the rescue. Whatever the effects of the ingestion of the bread, it is God who causes the result, the exact amount of energy, the precise increment of strength, the exact measure of increased acuity. Occasionalism powers every detail of every explanation by post-

${ }^{9}$ This passage from Malebranche's Meditations chrestiennesetmetaphysique is from Robinet et al. Ouvrés, complétés de Malebranche (20 vols., Paris, Vrin 1958-84) translated by (Ott, 2009b: p. 91). Ott also suggests that the doctrine of secondary causes adds nothing of value to the explanation of motion. 
ulating the intervention of God.

\subsection{Hume}

Now, if Hume is to be read as Malebranche "minus" God, we should expect to find changes consisting entirely of "chains" of disconnected events. After all, except for God, whether God acts directly or via secondary causes, there isn't a reason to think that one event (or event-kind) inevitably follows its causal companion. On the other hand, if events (or event-kinds) are not connected so that the occurrence of the former gives us a good reason for expecting the latter, then how did it come about that so many bright people have been misled into thinking that there are real causal connections in nature?

Hume's answer is not completely clear, although his basic insight is clear enough. Hume's analysis is that because we have found that events have been regularly associated with each other, we have come to expect that those associations will continue. This expectation will be reliable only if it is really true that the close associations we have discovered are indicative of the future. Is there any reason to think that they are? This is where Hume's famous argument against induction exposes the black magic of "projection". If the connection between cause and effect is necessary, then past experience must be projectable. But if the connection between cause and effect is necessary and hence projectable, then we should be able to discern the effect in the cause, just as (ITC) claims, and that, Hume insists, is just what we cannot do. On the other hand, if cause and effect are associated contingently, then the fact of their past contingent association will be indicative of future association only if past experience of projectability is itself projectable, and that clearly begs the question. Either way, the future merely follows the past, it is not shaped by it (Hume, 1739b: SBN, pp. 74-82; Hume, 1739a: N \& N, pp. 53-58). If God is always at the ready to validate our expectations, we are justifiably confident about the future when it is based upon careful examination and analysis of the past, just as a spoiled child is right to think that every wish will again come true on Christmas morning or on New Year's Day. But Hume claims that there isn't a reason to think that God does interject himself into every causal transaction, and even if he were, his intervention wouldn't provide a scientific explanation of anything (Hume, 1739a, Beauchamp, Ed., 2000: p. 86ff). ${ }^{10}$

\section{Specificity}

Now, Hume scholars, likeGalen Strawson and Peter Kail have argued that Hume can be plausibly read as a causal realist, meaning that "causal relations" are not merely patterns of expectations but are actual connections among events. Strawson's view is cautious and takes Hume to anticipate subsequent evolutionary explanations:

The present position acknowledges the force of direct realism, but grants

${ }^{10}$ The first of many editions of An Enquiry Concerning Human Understanding appeared in 1848. There were successive revisions. The reference above is from the final revision. (Beauchamp, $\mathrm{T}$. (1999) pp. xxxv-xlv) 
for the sake of argument the Humean view of the "true" basic content of experience of causation in the objects (nothing but regular causation). Thus it holds that our experience of Causation is filtered through a kind of evidential bottle-neck which delivers only regular-succession experience; but that it is then "intellect-enhanced (as in a computer-enhanced image), in a fully fledged concept-exercising creatures like ourselves...and in a way laid down by the 'wisdom of nature', or in other words, by evolution, into a genuine concept of Causation which genuinely applies it and is its own inexplicit way of correctly representing something essential to the actual nature of causation in reality" (Strawson, 1989: p. 250f).

Kail takes a similar, minimalist position in his "How to understand Hume's realism".

All realism need claim is that Hume's talk of hidden connections expresses a minimal preference for a metaphysical position whereby that is something worthy of the name power that underlies manifest regularities and that Hume supposes or presumes there is more to the world than those regularities (Kail, 2007a: p. 262). ${ }^{11}$

Both Strawson and Kail think that for Hume there must be something underlying the regularities of nature that validates the idea that there is aunifying principle that substantiates the appearance of connectedness. This seems to be reasonable, and very likely true at least on one interpretation of the idea that there must be "something underlying the regularities of nature". I nevertheless part ways with both Strawson and Kail in understanding what that "something" is. To begin, it is important to remember that Hume's own final words on the subject provide support for a realist view:

When a new object, endowed with similar sensible qualities is produced, we expect similar powers and forces, and look for alike effect. From a like body of like colour and consistence, we expect like nourishment and support (Hume, 1776, Beauchamp, Ed. 2000: p. 32).

Supporting the realist line of thinking is Hume's argument that bread nourishes due to its power, a secret power, to nourish. Here and everywhere it is important to distinguish secret or hidden powers from "occult" powers. Many philosophers during the $16^{\text {th }}$ and even $17^{\text {th }}$ centuries considered appeals to occult powers to be pseudo-explanations. Complaints of this sort are emphasized by Malebranche. Malebranche complains that the terms "gravity", "form", "nature" and the like do not call up the idea of being nor of mode, and in fact are without sense. Those powers are properly deemed to be occult in the sense that they operate in undiscoverable obscurity. Many references to them also appear to involve vicious circularity, as for example when we explain the tendency of a certain drug to put us to sleep by virtue of its dormitive powers (Clarke, 1989: p.

${ }^{11}$ For a fuller development see also (Kail, 2007b: pp. 77-102) in Reed \& Richmond (2000). The New Hume Debate (pp. 253-267). London: Routledge (p. 10). 
166f, The Search After Truth, Elucidation XII). Malebranche's conclusion that reference to basic forces is without sense leads him to his occasionalism, but must other skeptics resort to occasionalism as well? That is what drives philosophers like Strawson and Kail to their (weak) forms of casual realism.

Yet some commentators have resisted the realist reading of Hume on causation. Perhaps the most trenchant criticism of the causal realist reading of Hume comes from Kenneth Winkler. As Winkler correctly observes, Hume opposes the occasionalist alternative to causal realism. Moreover, Hume is "unwavering (in his belief) in the efficacy of force and energy". Even so, Winkler claims that Hume's understanding of causation can be deconstructed so that causation amounts to no more "than constant conjunction, or the expectation to which such conjunction gives rise" (Winkler, 1991: p. 573). Winkler's point is that for all the talk, the causal realist reading of Hume really does not advance our understanding. How can a vague, underlying power turn the expectation of continued constant conjunction into a connection?

Occult causes are causes that act but are not located in the larger complex web of explanation offered by genuine scientific theory. Secret causes (that are not occult) operate within a wider explanatory context. I suggest that these views can be reconciled by the specificity and comprehensiveness of scientific explanation. Secret causes are not occult if the way in which they operatecan be discovered; but, is that enough to give a complete explanation, for example, of the nourishment of bread? Mustn't we ask just how enzymes facilitate the reduction of proteins to amino acids? We have seen from the earlier discussion of Hill and Schmidt that exactly how bread nourishes requires an extraordinarily complicated analysis. Hume is a causal realist insofar as he, unlike Malebranche, believes that secret causes must operate by means that are in principle discoverable and can be integrated into wider explanatory schemes; otherwise those putative causes are occult (Hume, 1776, Beauchamp, Ed., 2000: p. 29f).

\section{Newton, Einstein and the Terminus ad Quem of Causes of Motion}

As have seen in the case of bread and the nourishment, sometimes causes that are hidden or secret at one time are subsequently revealed at a later time. But the explanation given by Hill and Schmidt cries out for further explanation. Just how do enzymes cause the reduction of proteins to amino acids? The search for an explanation of those phenomena ultimately takes us to the foundations of chemical reactions, to atomic numbering and the Schrodinger Wave Equation; ${ }^{12}$ but can even that be the end of the matter?

The same problem about the end of explanation also arises at the macro level. For example, unexplained deviations in the orbits of the outer planets led scientists to conclude that there must be an undiscovered planet that could account

\footnotetext{
${ }^{12}$ For an excellent, sophisticated introductory discussion of Schrödinger's Wave Equation, see Freiberger, Marianne (2012). "Schrödinger's Wave Equation, what is it? Plus Magazine, Living Mathematics. This introductory article presupposes a basic understanding of differential and integral calculus.
} 
for the orbits of the outer planets. That planet turned out to be Neptune (Feynman, 1965: p. 15). However, unexplained deviations of orbital paths of planetary motion are not always explained by discovering new objects. For example, Newton was puzzled about the orbit of Mercury, as his laws failed to accurately predict the precession of the perihelion Mercury (Cohen, 1985: p. 181). At first some thought that an undiscovered planet, tentatively named "Vulcan," must be the cause of the deviation in the orbit of Mercury; however, history left it to Einstein's theory of General Relativity to account for the deviation in Mercury's orbit, not by resorting to an undiscovered body but rather to the "deformation" of space itself, which is due to the enormous mass of the sun (Einstein \& Infeld, 1960: p. 238f). Shall we conclude that Newton was just wrong about the terminus ad quem of gravity? As we have seen, Newton concludes that it is the force of gravity that is revealed by the universal law of gravitation, but the only explanation of the force of gravity is God. Yet, for Einstein, gravity affects space itself. If large masses deform places that would otherwise rest comfortably in Euclidean configurations, there obviously arises yet another question, which is: What accounts for the effect of the masses upon space? The discovery of a new object or force always seems to demand further explanation. Ultimately the universe is configured in a certain, particular way due to its fundamental forces, forces that cannot be explained further by experimental science but rather is matter for natural philosophy, which for Newton includes God.

Einstein came close to agreeing with Newton on this point, despite the fact that the General Theory of Relativity upended Newtonian physics. Einstein famously offered words to the effect that the study of physical science is spiritually rewarding because from it we learn how God "thinks", where, following Spinoza, Einstein conceived God as immanent rather than transcendent and personal. Perhaps it was this conviction that led Einstein to the view that ultimately chance could not play a role in the scheme of things, as though chance would limit the immanent god's intelligible, rational nature. It was in this connection that Einstein made his famous claim against indeterminacy: "Gottwürfeltnictht"; generally and liberally translated as: "God does not play dice with the universe" (Einstein, 1958: p. 25; Hoffman, 1972: pp. 193-195). Einstein and Newton disagree about the nature of God and disagree about the relation of gravity to mass and acceleration, but from a philosophical point of view, they are almost in complete agreement. Each believes that there are fundamental physical forces that determine the behavior of physical entities. Each thinks that those behaviors can be accurately represented by projectable regularities (that is, by laws). Those laws, they believe, are necessary. Each thinks of God as the terminus ad quem of scientific explanation, but they do not think of the terminus ad quem of scientific explanation as a scientific proposition or belief. Each distinguishes experimental science, that is physical science, from natural philosophy and religion.

All this brings us to the main point: What is to keep us from concluding that gravity just is whatever makes the planets go around the sun, and thereby to save us from the conclusion that gravity, or the cause of it, is just another occult 
power? The answer is that gravity is not merely the force that makes the planets go around the sun. It enables us to predict the precise time and location of planet, comets, asteroids and man-made satellites. Moreover, gravity does not only enable us to predict the locations of planets, but to calculate the time it takes freely falling bodies to reach the ground. Indeed forces like gravity and the electro-magnetic forces not only predict the fact, place and time of events, but they also enable us to make precise predictions about a wide variety of phenomena, like the pressure of gas in a closed container at a certain temperature, or the sound of an object on the basis of the frequency of its "waves", or the color of an object from the wave-lengths of the light the object reflects. What keeps forces like gravity or inertia from being occult is their specificity and the comprehensiveness of the explanations they generate.

In his "Notes on Good and Excellent Hypotheses" Robert Boyle suggests that comprehensiveness is an important criterion in evaluating scientific theories. (Boyle, 1675; Stewart, 1991: pp. xx, 117) Newton's theory of gravitation satisfies that standard, at least in a purely Euclidean context. Einstein improves greatly upon Newton. Both provide a unified explanation of terrestrial and celestial motion that holds throughout the entire universe. Gravitational force is not occult because it is not merely the force that makes things fall or rotate as they do.$^{13}$ It is the force that accounts for the location of each thing at each time in the universe. Parallel observations apply to the micro-world; to the world of molecules and atoms that are described by generalizations like the Schrödinger Wave Equation.

\section{Was Hume Really Malebranche Minus God?}

This last point gets us to the main difficulty in reading Hume on causation. Hume claims that events are loosely associated; yet, Hume is also a champion of the empirical method as it is defined by Newton. Therefore, Hume is committed to causes as essential components of scientific explanation even though the relation between cause and effect is contingent. How are these apparent irreconcilables to be reconciled? Newton's laws, and other natural laws, for example those characterizing hydrolyzation, are actually meant to be applied in ideal contexts. So, the laws of freely falling bodies will predict the exact time it takes an object to fall to the ground of Earth ignoring other forces, like the resistance of air, or other bodies that also attract the object, or updrafts of the wind. Likewise, bread nourishes, assuming that intervening causes like malignancies or viruses or allergies or poisons do not interfere. So, it is natural for us to think of the laws of mathematical physics as necessary expressions of the operation of forces in ideal contexts without thinking that there are any actual events that are necessary. ${ }^{14}$

${ }^{13}$ Philosophers like Nancy Cartwright will want to qualify this statement. Cartwright's long-standing argument is that natural phenomena are the products of a multiplicity of forces, which are not coordinated by over-arching unifying principles (Cartwright, 2016: p. 78) in (Cartwright \& Ward, 2016) Rethinking Order after the Laws of Nature (pp. 65-78). London: Bloomsbury. In this, it is perhaps fair to conclude, Cartwright is echoing Newton. Gravity is not occult, but the force by which it operates is occult (or, as a Cartwrightan might well argue), the "force" by which gravity and other fundamental forces are coordinated would be occult.) 
We are now in a position to answer the primary question posed in this paper: Is Hume really Malebranche minus God? The answer is: No! Here's why: to be sure, Malebranche was aware that causal explanation is not merely a matter of predicting the existence of an effect but also of predicting the precise time and place of its location. Moreover, Malebranche thought that he had a perfectly good response to demands for specificity, and that response is the ultimate: God. The reason that each event occurs is that God wills it, and the reason that it occurs where and when it occurs is that God wills it to occur precisely there and then. The problem is that this makes Malebranche's God a truly occult cause, which functions just like the dormitive power. The dormitive power, whatever it is and however it operates, is what induces sleep, and that is all there is to it. Yes, indeed-something induces sleep; name it as you please. Something accounts for the fact, place and time of each event; call it God if you will, but each explanation is vacuous.

Perhaps it will be argued that Malebranche's argument cannot be so easily put to rest. Some will surely remonstrate that we know a great deal about God besides the fact that God causes the fact, place and time of each event. Among those facts are attributes of God that are revealed, and, besides those, examples of God's work that fall outside the regular course of nature, like miracles (and perhaps among them, otherwise inexplicable experiences of visions or voices). God is not only the one who causes the fact, place and time of every event that occurs in the regular course of nature, but also God is for sure the one who created the heavens and the earth; who intercedes repeatedly in human affairs. Yet, those features of the divine do not explain how God causes anything, and that is why it is that Newton correctly insists that appeals to God are expressions of religious faith and are not part of scientific theory. What could be clearer than the unfortunate fact that Malebranche's strategy just makes God into the allpurpose explanatory device for whatever happens, whether it occurs within the ordinary course of nature or not?

As we have seen, Hume clearly recognizes the importance of specificity to scientific explanation:

The first question that occurs on this subject is always whether the object shall exist or not: The next, when and where it shall begin to exist. If the removal of the cause be intuitively absurd in the one case, it must be so in the other: And if that absurdity be not clear without a proof in the one case, it will equally require one in the other (Hume, 1739b: SBN, pp. 78-82;

\footnotetext{
${ }^{14}$ Our experiences of causally related objects are loosely associated because there are wide varieties of forces acting upon objects in each situation. Now, someone is bound to suggest that a complete physics would take all this into account and come up with grand integrating principles that would validate the views that there are necessities in nature after all. That there are grand integrating principles is what Cartwrightans deny, and it also seems to me that contemporary physics suggests that even if there are grand, integrating principles, they will forever elude us. In any case, from Hume's perspective even if there were over-arching principles, we could never have complete, unshakeable confidence in them because we could never have adequate grounds for believing that they are projectable.
} 
Hume, 1739a: N \& N, pp. 56-58).

Hume is completely out of sympathy with Malebranche's theory of causation. Famously, Hume introduces two definitions of "cause" in the Treatise. One of them essentially says that the cause occurs before the effect, is contiguous with the effect and is always followed by the same effect. The other is like the first except that it states that not only does the putative effect always follow the cause but that it would follow the cause if the casual event were to occur. That there are two definitions has excited considerable controversy. For our purposes, however, it will suffice to note that Hume's understanding of causation supports subjunctive and counter-factual claims If $\mathrm{C}$ is the cause of $\mathrm{E}$, then if $\mathrm{C}$ were to occur, E would occur; furthermore, if $\mathrm{C}$ is the cause of $\mathrm{E}$, then if $\mathrm{C}$ had occurred, $\mathrm{E}$ would also have occurred. $\mathrm{C}$ and $\mathrm{E}$ are not accidentally associated; on the contrary, they go hand and hand throughout the course of nature. This does not show that the two are necessarily connected. All that has been claimed is that two always go hand in hand-not that they must, which means that regularity in nature is contingent. Hume acknowledges the awkwardness of the situation: It cannot be demonstrated that any two events will always go hand in hand, but if there is a genuine causal relation between the two, they always do go hand in hand; but might not events pairs that always walk hand in hand go together merely by accident?

This raises a further objection to the Humean account of causation that might advantage occasionalism. Might an occasionalist argue against Hume that God's intervention does not vitiate the fact that the divine will always accords with the necessary laws of nature? Therefore, might it not be urged, that God is not an occult cause after all, because God's volitions are specific and fall into the recognizable patterns of physical science? The specificity of experimental science would be preserved. It may very well be that this conception of God's relation to nature is true, but it is not occasionalism: that is because even if God's willing perfectly accords with the specificity of natural laws, the laws on this account do not derive their necessity from God's willing; their necessity derives from the operation of basic forces like gravity and electro-magnetism. Even if God's willing case by case de facto reveals the pattern of scientific laws, the explanation of events by those laws need not refer to God but only to the regularities. Whatever is explained by the regularities and theories of experimental science is explained just as well without God as with God. What is not explained as well without God is the existence of the forces that account for the regularities. This is indeed Newton's view, but it is neither occasionalism nor Hume's skeptical empiricism. Hume differs from Newton at this point as surely as does Malebranche because Hume denies that there are necessities in nature. According to Newton, God set up the universe so that certain forces determine the regularities of nature. God majestically and mysteriously determines the constitution of those forces, but how those forces are determined by God is not a matter for experimental science but rather of natural philosophy. Hume departs from Newton in denying the necessity of the grand laws of natural science; occasionalism departs from New- 
ton in attributing each application of the laws of nature to the unmediated will of God.

We may summarize the main points of comparison among Newton, Einstein, Malebranche and Hume as follows:

Malebranche: Malebranche acknowledges the problem of specificity. He claims that every detail of nature is willed by God. If there are regularities or patterns in nature it is only because there are regularities and patterns in God's willings of each and every event, however finely delineated.

Newton: Newton claims that there are necessities in nature, like the Universal Law of Gravitation, but he attributes them to fundamental forces, like gravity, which are created by God. The attribution of divine intervention in creation is matter of natural philosophy but not experimental science.

Einstein: Einstein also claims that there are necessities in nature. However, like Newton, he does not attribute them to God as a matter of experimental science but rather as a matter of religion, according to which God is immanent and whose rational nature is revealed in the grand principles of experimental science.

Hume: Hume acknowledges that there are law-like universal generalizations that have accurately described nature, just as Newton claims. However, he denies that they are necessary or even that we have sufficient arguments for believing that they will continue to hold in the future.

Hume's position is problematic in a unique way. If we do not have good arguments that warrant belief that the laws of science will obtain in the future, why do we have that confidence in them, and how could that confidence be justified? Hume's answer is that the method of experimental science can be applied not only to physics and mathematics but also to the "science of man", and hence to our efforts that constitute scientific research. A charitable reading of Hume, which I advocate below, is that he thinks that the science of man reveals and explains the regularities in human thought, which explains why it is that we have confidence in our scientific beliefs, about nature and about ourselves. To the extent that we are satisfied that our science explains nature, we are satisfied that it explains our explanations of nature.

\section{Could Hume's Philosophy Be Newtonian Science Minus God Plus "the Science of Man"?}

For the Newton of the Principia, mathematics (quantitative reasoning) pertains to the essence of experimental science. Newton lays down four methodological principles that he believes should be observed in scientific investigation:

N1) We are to admit no more causes of natural things than such as are both true and sufficient to explain their appearances.

N2) Therefore, to the same natural effects we must, as far as possible, assign the same causes.

N3) The qualities of bodies, which admit neither intensification nor remission of degrees, and which are found to belong to all bodies within the 
reach of our experiments, are to be esteemed the universal qualities of all bodies whatsoever.

N4) In experimental philosophy we are to look upon propositions collected by the general induction from phenomena as accurately or very nearly true, notwithstanding any contrary hypothesis that may be imagined, till such time as other phenomena occur, but which they may either be made more accurate, or liable to exceptions. ${ }^{15}$

For Newton, these are the rules by which we judge cause and effect. There is a reference to quantification in (N3), but other than (N3) the rules do not appear to be distinctively quantitative. The mathematical principles so familiar natural philosophers are therefore specific to certain problems arise concerning causal reasoning. Newton's rules are familiar to contemporary scientists, but perhaps (N3) and (N4) require special comment. (N3) refers indirectly to mass or bulk. The mass or bulk of an object in Newtonian physics is constant, wherever it is found. ${ }^{16}$ It would be a serious mistake to confuse the mass of an object with its weight. Weight is a relative concept and essentially a kind of force. The weight of an object at the surface of the earth is the measure of the force of the gravitational attraction between the object and point mass of Earth. The weight of an object on the moon of Earth is a small fraction of the weight of the object on Earth, because our planet is far more massive than its moon. Although the weight of the object is less on the moon than the Earth, the mass is the same. According to Newton, mass does not admit of intensification or remission of degrees.

(N4) is or is very much like the principle of induction, which Hume claims cannot be demonstrated. Newton, on the other hand, takes induction to be a rule of the methodology of science, and it is therefore presumed to be true; perhaps even an essential component of the methodology of empirical science. We have already seen that Newton allows that it might be necessary to appeal to the divine in order to explain the fact of gravity, although as we have also seen, Newton emphasizes that an appeal to God cannot count as a step in "experimental" philosophy, which is not to say that the appeal is wrong-headed or unreasonable-it is only to say that the appeal is not part of experimental science, in another word, physics. Newton's own great work in experimental philosophy revealed the mathematical principles of motion. ${ }^{17}$ The success of the project was and is overwhelming, and it was and perhaps is natural to think (or to hope) that all experimental science is ultimately mathematical (Feynman, 1965: pp. 55-58).

Hume, on the other hand, has a broader conception of experimental science, he expressly states that philosophers are concerned with the "science of man", which is to say with human nature. He proclaims that all the sciences, even

\footnotetext{
${ }^{15}$ Newton 1686 (Thayer, 1953: p. 3).

${ }^{16} \mathrm{By}$ the way, this is a familiar point that distinguishes Newton from Einstein. Relativistic mass (in Einstein's theory) is equal to the Newtonian mass divided by the square root of 1 minus the square of the velocity of the object divided by the square of the velocity of light; that is: $M_{R}=M_{N} /(1-$ $\left.\left(\mathrm{V}^{2} / \mathrm{C}^{2}\right)\right)^{1 / 2}$. (For a simple, straightforward derivation see: (Halliday \& Resnick, 1974: p. 142).)

${ }^{17} \mathrm{Of}$ course we now regard Newtonian mechanics to be a special case of relativistic mechanics, which would hold if the total massin the universe were zero.
} 
"Mathematics, Natural Philosophy and Natural Religion" are dependent of the science of Man (Hume, 1739b: SBN, p. xv; Hume, 1739a: N \& N, p. 5). The disciplines that pertain to the science of Man include Logic, Morals, Criticism and Politics. Hume thinks that we can find generalizations that characterize human nature, and that those generalizations are based upon causal analyses, which need not be quantitative and need not mimic the Mathematical Principles of Natural Philosophy. Human reasoning is broader than quantitative reasoning. So, although Newton's rigor inspires Hume, Hume hopes to carry on an examination of reason that extends far beyond the quantitative reasoning that characterizes the essence of Newton's methodology in the Mathematical Principles of Natural Philosophy.

Hume identifies eight rules by which we judge of causes. Full treatment of the rules is controversial and beyond the scope of this paper; for our purposes it will be sufficient to take account of some of the obvious points. Hume's rules do incorporate some of Newton's rules, but they pointedly modify (or arguably exclude) one of Newton's rules. In particular, on one interpretation of (N4), Hume does not follow Newton in assuming that "in experimental philosophy we are to look upon propositions collected by the general induction from phenomena as accurately or very nearly true". Indeed, Hume thinks that (N4), which is or is close to the principle of induction, cannot itself be justified by either principles of experimental reasoning or by reasoning based upon "relations of ideas". On the other hand, Hume does think that inductive reasoning is essential to experimental philosophy (or the method of experimental reasoning), and Hume unquestionably thinks that experimental reasoning is a model for all rational inquiry.

The first two of Hume's rules go beyond Newton's significantly, and the remaining rules do not correspond one-to-one with Newton's. The first two of Hume's rules are:

(H1) The cause and effect must be contiguous in space and time.

(H2) The cause must be prior to the effect (Hume, 1739b: SBN, p. 173;

Hume, 1739a: N \& N, p. 116.f).

These rules go further than Newton in making assumptions about the nature of causation a part of the methodology of natural science. Perhaps Newton would have welcomed them as an amplification of his own set of rules, but I think that it is more likely that Newton would have worried first of all about the fact that his own laws of motion are retrospective as well as prospective, which is to say that the laws of motion are symmetrical and can explain the course nature has taken as well the course that it will take; or in other words. Newton's laws can "retrodict" as well as predict ${ }^{18}$ (Feynman, 1965: pp. 85-107). Secondly, there

\footnotetext{
${ }^{18}$ Thus, the laws enable us to predict where and when the ink will spill from the bottle (for example on the table cloth), but it is counter-intuitive to think that the same laws are sufficient to show us how to get the ink back in the bottle, which is explained by the obvious fact that it is far more complicated to remove the spilt ink from the cloth and put it back in the bottle than it is to spill the ink on the table cloth.
} 
is the matter of the contiguity of causation. For early modern philosophers like Descartes, who asserted the existence of the plenum, it might be possible to insist that cause and effect are contiguous. However, gravity operates at a distance, and that does not rest comfortably with Hume's insistence on the contiguity in space and time of cause and effect.

The last six of Hume's rules appear to be drawn from Newton, and are included below.

(H3) There must be a constant union betwixt the cause and effect. "Tis chiefly this quality, that constitutes the relation".

(H4) The same cause always produces the same effect, and the same effect never arises but from the same cause.

H5) Where different objects produce the same effect, it must be by means of some quality, which we discover to be common amongst them.

H6) Differences in the effects of two resembling objects must be attributed to that particular, in which they differ.

H7) When any object encreases or diminishes with an encrease or diminution of its Cause, "tis to be regarded as a compounded effect, derived from the union of the several difference effects, which arise from the several different parts of the cause.

H8) [A]n object which exists for any time in its full perfection without producing another, is not its sole cause; but is assisted by some other principle, which pushes it from its state of inactivity, and makes it exert that energy, of which it was secretly possest" ${ }^{19}$ (Hume, 1739b: SBN, p. 173; Hume, 1739a: N \& N, p. 116f).

(H5) and (H6) refer directly to qualities. Qualities in the "sciences" of "morals, criticism and politics" need not quantitative. Throughout his writings Hume tries to extract general maxims or rules that characterize the science of man. For examples, these qualities include moral approbation or approval, which is identified as a pleasant feeling. They also include the pleasant feeling of pride, which arises when we reflect upon those things that in turn reflect favorably upon us. Besides, there are general maxims that characterize the "science of man" itself; for example "that when any impression becomes present to us, it not only transports the mind to such ideas as are related to it, but likewise communicates to them a share of its force and vivacity" (Hume, 1739b: SBN, p. 98; Hume, 1739a: N \& N \$1, 3, 8, p. 69).

Finally, as Noxon observes, (N1) is essentially a "rule of parsimony", ${ }^{20}$ and arguably appears in Hume as (H1). (H5) is the famous principle of the common cause. This principle addresses obvious and familiar cases, for example, when events appear to be causally related to each but actually are the result of a common cause. Just as (H4) mimics (N1), (H5) appears to correspond to (N2).

\footnotetext{
${ }^{19} \mathrm{By}$ the way, this passage provides direct and arguably conclusive textual evidence for the view that at least one of the eight rules by which to judge of causes and effects contains empirical principles that are themselves established by the experimental method.

${ }^{20}$ Noxon, 1973: p. 82.
} 
Hume's eight rules are meant to define the standards by which we judge causal reasoning, or the attempts to give "proofs" of causal relations, that is, to establish with a nearly certain level of probability that objects stand to each other as cause and effect. But what justification does he have for the rules? Are we able to produce either a demonstration or a "proof" for the rules themselves? Hume's famous answer is that we are not. His basic argument for this skeptical conclusion is that causal knowledge or belief must extend to the future, but, as we have already seen, we cannot justify the hypothesis that the future will resemble the past either by a demonstration or by a causal argument. We know that no demonstration is available because the claim that the future resembles the past is ampliative, and we know that no causal argument will do because causal arguments themselves presuppose that the future resembles the past, which is to say that past correlations will be indicative of further correlations. Even so, Hume believes that successful causal arguments, viz, arguments that follow the eight rules by which to judge of cases and effects, establish cause and effect relations with some degree of probability (in extreme cases, like the proposition that the sun will rise to-morrow, without any degree of uncertainty).$^{21}$ It is worth emphasizing, although it is not usually emphasized, that Hume's argument against projectability does not show that we actually have the slightest reason to doubt projectability. Just as we cannot prove that the sun will rise tomorrow does not mean that we have any reason to think that it will not rise as usual. In fact, if an anomaly occurred that undermined the laws of nature, experimental science would force us to struggle for an explanation of the anomaly. That of course is just what happened when Einstein explained the orbit of Mercury by the theory of Relativity.

Now if we compare Hume and Newton, I think that it is clear that Hume regards the mathematical reasoning of Newton's works to be paradigmatic examples of natural science. But Hume, like Newton himself, recognizes that there is more to natural philosophy that quantitative reasoning. On the other hand, the two dramatically differ on the role of revealed religion as an explanation for natural phenomena. Newton is content to allow revealed religion to play a part, as long as no one thinks of that part as scientific or as a part of the experimental method. Hume denies the revealed religion has any part to play in understanding "causal laws". Hume is what we get we accept Newton's experimental physics but foreswear the appeal to God that Newton's natural philosophy allows. That makes causal laws contingent for Hume, but Hume does not rest there. He explains that the casual laws of nature are complex, and fit into intricate patterns that include not only the mathematical principles of philosophy but also the general rules that characterize human reasoning and belief formation, which are an integral part of the "science of man". So, if we identify Newton with experimental science, and we add to it what Hume calls "the science of man", we get a conception of causal reasoning that amounts to Newton's experimental science

${ }^{21}$ See "Belief Based on Induction" (Hume, 1739b: SBN, pp. 78-80; Hume, 1739a: N \& N, pp. 56-58) for more on this issue. 
ofplus Hume's science of human nature. Hume is not merely Malebranche minus God because Malebranche minus God degrades natural science to a plethora of unrelated facts about nature. Hume, like Newton, insists that the grand laws of physics as well as universal generalizations that are universally accepted locate particular events within wider structures. Newton saves us from doubting the laws of nature by appealing to God, but Newton does not have an argument from experimental science to show that God will not change is his mind about the organization of the universe. Finally, when we contemplate a change in the course of nature, even with respect to the location of an event, we are contemplating a change in the structure of the universe, as it is revealed by the specificity and comprehensiveness of natural science and even by common sense. To imagine an anomalous event is not like imagining winning a lottery, where we know in that someone, sometime will win; it is rather imagining a change in the course of nature itself.

\section{Conclusion}

The problem with the Hume-is-Malebranche-minus-God theory is that without God Malebranche does not have any way to explain the specificity of natural laws or the comprehensiveness of scientific theory. The idea that God simply validates each specific instance of a natural law not only appears to be ad hoc but also deprives the natural laws of explanatory power. If the natural laws did have explanatory power independently of God, but upon each application is willed by God, then the application would not require God because the natural laws would perfectly describe and predict independently of God. So, "Malebranche minus God" is not Newton. Yet, although Newton affirms the role of God, for Newton God merely provides the speculative, philosophical foundation of natural science. Experimental science and physics never contemplate the intervention of God. Rather, God sets the forces in motion that the natural laws describe. Hume accepts Newton's view of the natural laws, but thinks that we account for our confidence in them not by appealing to God but rather by recurring to the laws or principles of human nature. Those laws account for the fact that we affirm the very laws that Newton discovered. Hume does not seek to reveal the grounds of the truth of the laws of nature but rather the grounds for our belief in them. One might say that Hume fails to be Newton in the first place because Hume neither affirms the objective validation of the nature's basic forces nor the God who created those forces. However, the appeal to God is not a matter of experimental science, as Newton concedes. Hume and Newton are therefore in the same boat when it comes to assurance of the constancy of nature. Newton does not believe that he can rationalize our acceptance of the natural laws without appealing to God, but Hume claims that the science of man, which borrows the experimental method from Newton and ultimately Boyle, does explain our acceptance of Newton's laws and all laws like them. Furthermore, although Hume argues that we cannot demonstrate that our absolute confidence in natural science is justified, there isn't any reason to think that it is not justified. Therefore, Hume's 
natural philosophy is Newton's experimental science (that is Newton minus God) plus Hume's own principles of human nature (that are principles describing the nature of Man); in other words, to replace that worn out dull saw with a new sharper saw: Hume is Newton-minus-God-plus-Man.

\section{Limitations and Further Research}

The principal limitations of this paper are that Hume's rules by which to judge cause and effect are not compared in detail with Boyle's notes of good and excellent hypotheses or with Newton's own four rules of scientific reasoning. Moreover, the paper does not fully describe and evaluate the general rules that Hume believes characterize the "science of man". These limitations can be corrected only by a further, lengthy project. In addition, the paper does not seek to examine the relation between Samuel Clarke and Newton, which surely accounted in part for Newton's views about the relation of God to our understanding of nature. Finally, the argument that Malebranche cannot count on God to explain the specificity of nature takes the side of Aquinas in an ancient argument. Explaining that ancient argument in detail is yet another lengthy project. On the other hand, the paper has sought to defend the more modest, negative thesis that Hume's theory is not that events are merely closely associated, but rather that Hume and Humeans can count on the specificity and comprehensiveness of science to explain its explanatory success and to justify rejection of the claim that Hume is merely "Malebranche minus God". Furthermore, the paper has suggested that a better way to look at Hume is to see him not only as endorsing Newton's principles of mathematical philosophy but also as insisting that the methodology underlying Newtonian physics is embedded in a more complete, broader natural philosophy that Hume calls "the science of man". That "science of man" ideally will explain human behavior, including our acceptance of experimental science. To the extent that the science of man gains in specificity, it too will come to enjoy the credibility of the physical science that depends upon it. Obviously assessing the extent and prospects of "the science of man" is a further, immense undertaking.

\section{References}

Ariew, R., \& Watkins, E. (2009). Modern Philosophy: An Anthology of Primary Sources (2nd ed., pp. xx, 117, 284-293). Indianapolis/Cambridge: Hackett Publishing Company.

Aristotle (335 BCE). Physics (pp. 218-398). Hardie, R, \& Gaye, R., Trans. In R. McKeon (Ed.), The Basic Works of Aristotle 1941 (p. 285). New York: Random House.

Bell, M. (1997). Hume and Causal Power: The Influences of Malebranche and Newton. British Journal for the History of Philosophy, 5, 68-86.

Boyle, R. (1675). Stewart, M. A. (1991). Notes on Good and Excellent Hypotheses (pp. xx, 117). In R. Ariew, \& E. Watkins (2009).

Cartwright, N. \& Ward, K. (2016). Rethinking Order after the Laws of Nature (pp. 65-78). London: Bloomsbury.

Cartwright, N. (2016). Where Do the Laws of Nature Come From? (pp. 65-78). In N. Cartwright, \& K. Ward (2016). 
Clarke, D. (1989). Occult Powers and Hypotheses (p. 166f). Oxford: Clarendon Press.

Cohen, I. B. (1985). The Birth of a New Physics (pp. 180-84). New York/London: W.W. Norton \& Company.

Cottingham, J. et al. (1984) The Philosophical Writings of Descartes, Vol. II (pp. 1-53, 201). Cambridge: Cambridge University Press.

Descartes, R. (1641). Meditations on First Philosophy. In J. Cottingham et al., (Eds.), The Philosophical Writings of Descartes, Vol. II. Cambridge: Cambridge University Press.

Einstein \& Infeld (1960). The Evolution of Physics (Revised, p. 238f). New York: Simon and Schuster.

Einstein (1958). Out of My Later Years (pp. 21-31). New Jersey: Secaucus.

Feynman, R. (1965). The Character of Physical Law (pp. 15, 55-58, 59, 85, 107). Cambridge, MA: The MIT Press.

Finocchiaro (Trans. and Ed.) (2008). The Essential Galileo. Indianapolis/Cambridge: Hackett Publishing Company.

Freiberger, M. (2012). Schrödinger's Wave Equation-What Is It? Plus Magazine, Living Mathematics. http://plus.maths.org/content/schrödinger-1

Galileo (1638). Two New Sciences. In Finocchiaro (Trans. and Ed.) (2008), The Essential (pp. 50, 300-367). Galileo.

Gassendi, P. (1621). Fifth Set of Objections to Meditations on First Philosophy (\$289, p. 201). In Cottingham et al. (1984).

Guth, A. (2007). Isaac Newton and Richard Bentley, Letter 1 (1692). Cambridge, MA.

Halliday, D., \& Resnick, R. (1974). Fundamentals of Physics (p. 142). New York, John Wiley \& Sons.

Hill, R. L., \& Schmidt, W. H. (1962). The Complete Enzymic Hydroloysis of Proteins. The Journal of Biological Chemistry, 237, 389-396.

Hoffman, B. (1972). Albert Einstein Creator and Rebel (pp. 190-196). New York: New American Library.

Hume, D. (1739a). Norton and Norton (N \& N) (Ed.) (2006). A Treatise of Human Nature (pp. 4, 56-58, 86, 116f.). Oxford: Clarendon Press.

Hume, D. (1739b). Selby-Bigge and Nidditch (SBN) (Ed.) (1978). A Treatise of Human Nature (2nd ed., pp. xv, 80, 125, 173-176). Oxford: Clarendon Press.

Hume, D. (1776). Beauchamp, T. (Ed.) (2000). Essay Concerning Human Understanding (p. 32, 105). Oxford: Clarendon Press.

Janiak, A. (2014a). Newton: Philosophical Writings (p. 103). Cambridge: Cambridge University Press.

Janiak, A. (2014b). Newton's Philosophy $(\$ 1,2,4)$.

http://plato.stanford.edu/entries/newton-philosophy

Kail, P. J. E. (2007a). How to Understand Hume's Realism (pp. 253-267). In Reed and Richmond (2007) The New Hume Debate.

Kail, P. J. E. (2007b). Projection and Realism in Hume's Philosophy (pp. 77-102). Oxford: Oxford University Press.

Malebranche, N. (1674-5). The Search after Truth (Trans. T. H. Lennon and P. J. Obecalp). Cambridge: Cambridge University Press. In Nadler (Trans. and Ed.) (1992) Malebranche: Philosophical Selections (p. 94f).

Morris, W., \& Brown C. (2014). David Hume $(\$ 3,5)$. http://plato.stanford.edu/entries/hume

Nadler, S. (1992). Nicolas Malebranche: Philosophical Selections (p. 94f.). Indianapo- 
lis/Cambridge: Hackett Publishing, Company, Inc.

Newton, I. (1692-93). Newton's Third Letter to Bentley (p. 54). In H. Thayer, (Ed.), Newton's Philosophy of Nature: Selections from His Writings (p. 7).

Newton, I. (1713). Motte, A. (Trans.) (1729) Mathematical Principles of Natural Philosophy (2nd ed., pp. 284-293). London. In Ariew, R., \& Watkins, E. (2009).

Newton, I. (1718). Clarke, S. (Trans.) (1718) Optics (2nd ed., p. 291ff). London.

Noxon, J. (1973). Hume's Philosophical Development: A Study of His Methods (p. 82). Oxford: Clarendon Press.

Ott, W. (2009b). Causation \& Laws of Nature in Early Modern Philosophy (pp. 34-48, 95, 106-109). New York: Oxford University Press.

Ott, W. (Trans.) (2009a). In W. Ott, Causation \& Laws of Nature in Early Modern Philosophy.

Reed, R., \& Richmond, K. (2000). The New Hume Debate (pp. 253-267). London: Routledge.

Robinet, A. et al. Ouvrés, complétés de Malebranche (20 vols, Paris, Vrin 1958-84, pp. 34-48)

Schmaltz, T. (2013). Nicolas Malebranche (\$1, 24$)$. http://plato.stanford.edu/entries/malebranche

Stewart, M. A. (1991). Selected Papers of Robert Boyle (pp. xx, 117). Indianapolis/Cambridge: Hackett Publishing Company,.

Strawson, G. (1989). The Secret Connexion: Causation, Realism and David Hume (p. 250f). Oxford: Clarendon Press.

Thayer, H. (1953). Newton's Philosophy of Nature: Selections from His Writings (p. 54). New York: Hafner Press, Macmillan Publishing Co.

Winkler, K. (1991). The New Hume. The Philosophical Review, 100, 541-579. https://doi.org/10.2307/2185174

Zalta, E. (Ed.) Stanford Encyclopedia of Philosophy. Metaphysics Research Lab: Center for the Study of Language and Information. http://stanford.plato.edu/

Submit or recommend next manuscript to SCIRP and we will provide best service for you:

Accepting pre-submission inquiries through Email, Facebook, LinkedIn, Twitter, etc. A wide selection of journals (inclusive of 9 subjects, more than 200 journals)

Providing 24-hour high-quality service

User-friendly online submission system

Fair and swift peer-review system

Efficient typesetting and proofreading procedure

Display of the result of downloads and visits, as well as the number of cited articles

Maximum dissemination of your research work

Submit your manuscript at: http://papersubmission.scirp.org/

Or contact ojpp@scirp.org 